\title{
Microbial Synthesis of Detritus-Like Particulates from Dissolved Organic Carbon Released by Tropical Seagrasses
}

\author{
Mark L. Robertson, Aaron L. Mills, and Joseph C. Zieman \\ Department of Environmental Sciences, University of Virginia, Charlottesville, Virginia 22903, USA
}

\begin{abstract}
Dried leaves of Thalassia testudinum and Syringodium filiforme released $12.6 \%$ and $19.4 \%$, respectively, of their organic carbon as dissolved organic carbon (DOC) during $3 \mathrm{~d}$ of axenic leaching. When inoculated with microbes, the DOC was rapidly converted to bacterial aggregates of a size that could be ingested by macroconsumers. Large populations of ciliates and flagellates also developed, presumably feeding on the unaggregated bacteria. In treatments containing the residual macroparticulate organic carbon (MPOC), 75-95\% of the bacteria present were attached to the leaves, and suspended aggregates were not observed. The protozoan community was dominated by freeswimming flagellates that grazed on the suspended bacteria and were thus responsible for the absence of those forms. Total microbial populations in the DOC treatments were 10-12 times greater per unit of seagrass carbon originally added than in the MPOC containing flasks. These results show that seagrass DOC may rapidly be made available to higher consumers through processes that produce suitable sized food particles: viz., growth of protozoans on bacteria and formation of bacterial aggregates
\end{abstract}

\section{INTRODUCTION}

The contribution of macrophytes (seagrasses, marshgrasses, and macroalgae) to secondary productivity in coastal waters occurs primarily through detritus food webs (Mann, 1972; Fenchel and Jørgensen, 1977). In these food webs, microorganisms are the primary agents in the transfer of macrophyte organic carbon to consumer organisms (Odum and Heald, 1975; Tenore, 1975, 1977).

The emphasis of detritus studies has been on the fate of the particulate fraction of macrophyte carbon. However, macrophytes also release substantial amounts of dissolved organic carbon (DOC) under a variety of conditions. For living seagrasses, the release of photosynthetic products as DOC averages from 2 to $10 \%$ of the daily production in short term ${ }^{14} \mathrm{C}$ experiments (Brylinsky, 1977; Penhale and Smith, 1977; Wetzel and Penhale, 1979). In the temperate seagrass Posidonia australis community, $48 \%$ of the annual loss of carbon is as DOC (Kirkman and Reid, 1979). Macrophyte detritus also releases large quantities of dissolved organics; detached leaves of the freshwater mac- rophyte Scirpus subterminalis can rapidly lose 30 to $40 \%$ of their original carbon by autolysis and leaching (Otsuki and Wetzel, 1974). Zieman (1975) attributed the rapid weight loss of decomposing Thalassia testudinum leaves to leaching of DOC.

Microbes utilizing DOC can form particulates that are available for secondary consumers (Riley, 1963). Particle size is a significant variable in determining the availability of carbon as food for marine animals such as copepods (Mullin, 1963), fish (Durbin and Durbin, 1975) and benthic filter feeders (Owen, 1974). Microorganisms, through decomposition processes. may reduce particles of plant detritus to a size appropriate for consumption by protozoans or zooplankton. Conversely, the aggregation of microorganisms may produce particles large enough to be consumed by filter feeders or animals that feed on substrate surfaces (Alldredge, 1976).

The present study used laboratory simulations to compare the microbial processing of DOC and macroparticulate organic carbon (MPOC) derived from the tropical seagrasses Thalassia testudinum and Syringodium filiforme. The results of the investigation show 
that microbial processing of DOC from the grasses can lead to a rapid buildup of particles of a size that could be fed upon by many consumers.

\section{METHODS AND MATERIALS}

Fresh, green leaves of Thalassia testudinum (Banks ex Koenig) and Syringodium filiforme (Kutz) were collected from seagrass beds near Middle Torch Key, Florida, USA. Only leaves with no visible epiphytes were selected. The leaves were dried at $50^{\circ} \mathrm{C}$ and stored in sealed plastic bags with $\mathrm{CaSO}_{4}$ desiccant. Ash free dry weights (AFDW) were determined as weight loss upon ignition $\left(4 \mathrm{~h}\right.$ at $500^{\circ} \mathrm{C}$ ) (Dawes et al., 1979). AFDW as a percentage of dry weight was $64.1 \%$ and $61.5 \%$ for $T$. testudinum and $S$. filiforme, respectively. The organic carbon content of the leaf material was assumed to be $47 \%$ of the AFDW (Westlake, 1963).

The dry leaf material was sterilized by exposure to approximately 2.4 Mrads of gamma radiation from a Co-60 source (Mills and Alexander, 1976). After sterilization, four $500 \mathrm{ml}$-leaching flasks were set up for each of the seagrass species by aseptically placing $1.5 \mathrm{~g}$ of sterile leaf material in $250 \mathrm{ml}$ of autoclaved synthetic seawater (Instant Ocean, adjusted to a salinity of $31 \pm 0.5 \mathrm{ppt})$. The flasks were placed on a rotary shaker $(100 \mathrm{rpm})$ for $3 \mathrm{~d}$ at $25^{\circ} \mathrm{C}$. At the end of the leaching period, sterility tests were performed on each of the flasks by inoculating $1.0 \mathrm{ml}$ of the leaching liquor into seawater nutrient broth tubes and incubating the tubes at $30^{\circ} \mathrm{C}$ for $48 \mathrm{~h}$. No growth was observed in any of the tests.

After the leaching period, the contents of the flasks were poured through a $0.5 \mathrm{~mm}$ sieve. The material retained by this sieve was designated the MPOC fraction. Wet weights were taken and subsamples were dried and weighed for determination of wet weight/ dry weight ratios. The material passing the sieve was filtered through preweighed $0.45 \mu \mathrm{m}$ Gelman glass fiber filters and the filtrate was designated DOC. The filters were dried at $100^{\circ} \mathrm{C}$ and weighed to measure total recovery of particulate organic carbon after the leaching period.

The MPOC fraction of each grass was pooled for use as starting material for the decomposition study. In nature, finer material such as was collected on the $0.45 \mu \mathrm{m}$ filters would be the result of long term decomposition processes, and therefore was not used here. Three portions of Thalassia testudinum MPOC, each equivalent to $1.468 \mathrm{~g}$ dry weight $(0.442 \mathrm{~g} \mathrm{C})$, were placed in $700 \mathrm{ml}$ of filtered $(0.45 \mu \mathrm{m})$ artificial seawater (salinity, $31 \%$ ) in 2-l flasks. Three portions of
Syringodium filiforme MPOC, each weighing $1.141 \mathrm{~g}$ $(0.330 \mathrm{~g} \mathrm{C})$, were similarly treated.

Three aliquots $(250 \mathrm{ml})$ of the pooled DOC fraction of each grass were diluted to $700 \mathrm{ml}$ with filtered artificial seawater in 2-1 flasks. The aliquots contained 142.4 and $197.4 \mathrm{mg}$ DOC for Thalassia testudinum and Syringodium filiforme, respectively.

A single flask was prepared with only filtered seawater to serve as a control for endogenous microbial growth. All 13 flasks were inoculated with $10 \mathrm{ml}$ of water from a marine aquarium which contained decomposing seagrass. The flasks were incubated in darkness at $20^{\circ} \mathrm{C} \pm 1.5 \mathrm{C}^{\circ}$ for $14.5 \mathrm{~d}$. Aerobic conditions were maintained by continuous bubbling of air through the flasks. The salinity of the suspensions was measured at each sampling time, and any evaporative losses were made up by the addition of distilled water. At no time was the salinity increase greater than $1 \mathrm{ppt}$ in any flask.

Thus, the 2 fractions resulting from the leaching process, MPOC and DOC, were quantitatively partitioned such that the proportions of each that resulted from leaching a given weight of leaf material were decomposed separately. The actual concentrations of carbon were different in the MPOC and DOC flasks of each seagrass, as most of the organic matter of the starting material was left as MPOC. However, this design allowed a quantitative comparison of the microbial response, under identical nutrient and volume regimes, to the seagrass organic matter that resulted from leaching.

The flasks were sampled on Day $0,2,5,9$, and 14 of the incubation. At each sampling time, DOC concentrations and microbial numbers were determined for each of the 13 flasks. One subsample from each flask was passed through a $0.2 \mu \mathrm{m}$ filter and the DOC content determined as the difference between the total carbon content and the content of inorganic carbon (measured as $\mathrm{CO}_{2}$ evolved from an acidified portion of the sample) using a Beckman Two-Channel Total Carbon Analyzer (Model 915).

One $1.0 \mathrm{ml}$ sample of the liquid from each flask (DOC and MPOC treatments) was used to enumerate suspended bacteria and protozoans following the acridine orange direct count (AODC) method of Hobbie et al. (1977). The number of aggregated bacteria was estimated in the following manner: During AODC preparation, the aggregates settled onto the filter in sheet-like forms that were seldom thicker than 3 cells. The difference in staining characteristics of the aggregated cells and the surrounding matrix made it possible to estimate that an average of $67 \%$ of the cross sectional area of an aggregate was occupied by cells. The mean cross sectional area of a bacterial cell was calculated to be $0.47 \mu \mathrm{m}^{2}$ using the dimensions from 
the biomass estimates listed below. The number of cells in the aggregate was therefore estimated by measuring the proportion of the microscope grid area occupied by aggregates, and multiplying this value by the average cross sectional area of an aggregate occupied by bacteria, viz., 0.67 , and the average cross sectional area of a bacterial cell $\left(0.47 \mu \mathrm{m}^{2}\right)$. In aggregates that were many cell layers thick, this method would result in an underestimate of bacterial numbers.

One sample of leaf material (approximately $10 \mathrm{mg}$ dry weight) was removed from each MPOC flask at each sampling time for enumeration of leaf-attached bacteria following the AODC procedure of Rublee et al. (1978). Briefly, the leaf sample was macerated for 5 min in a Virtis Tissue Homogenizer (Model 23) with $100 \mathrm{ml}$ of filtered $(0.2 \mu \mathrm{m}) 2 \%$ formaldehyde-seawater solution. A $1.0 \mathrm{ml}$ subsample was removed from the slurry for the AODC procedure. The remaining $99 \mathrm{ml}$ was filtered through a glass fiber filter, and dried and weighed to determine the weight of the leaf sample.

All AODC samples were processed and counted within $48 \mathrm{~h}$. At least 10 microscope fields were counted for every AODC determination. Population densities are reported as the number of microorganisms present per milligram of seagrass carbon originally added at the beginning of the experiment.

Bacterial biomass was estimated on the basis of average cell volume from the measurement of the dimensions of 50-100 cells in each of 21 different AODC samples from the various treatments. The conversion factors of Ferguson and Rublee (1976) were used to calculate bacterial carbon: specific gravity $=1.1$, a dry weight to wet weight ratio of 0.23 , and carbon content $=34.4 \%$ of the dry weight.

Protozoan cell volumes were estimated by measuring the dimensions of at least 25 flagellates and 25 ciliates in 12 and 6 AODC samples, respectively. Protozoan biomass was calculated using the conversion factors reported by Rigler et al. (1974): specific gravity $=1.0$, and dry to wet weight ratio of 0.072 . The carbon content of the protozoans was assumed to be $40 \%$ of the dry weight.

\section{RESULTS}

The leaves of Syringodium filiforme released $194 \pm 4 \mathrm{mg} \mathrm{DOC} \mathrm{g}^{-1}$ leaf carbon, and Thalassia testudinum leaves released $126 \pm 1 \mathrm{mg} \mathrm{DOC} \mathrm{g}^{-1}$ leaf carbon after $3 \mathrm{~d}$ of leaching under sterile conditions $(\overline{\mathrm{x}} \pm 1$ standard error of the mean, $\mathrm{n}=4)$. S. filiforme leaves released 1.6 times as much DOC per unit of leaf carbon than did $T$. testudinum leaves.

For Thalassia testudinum, $79.4 \pm 5.4 \%$ of the original dry weight of leaf material added to the leaching flask was recovered on the $0.5 \mathrm{~mm}$ sieve as MPOC, and $13.1 \pm 0.4 \%$ was recovered on the $0.45 \mu \mathrm{m}$ filters $(\overline{\mathrm{x}} \pm 1$ S.E.M., $\mathrm{n}=4)$. For Syringodium filiforme, $65.4 \pm 1.2 \%$ was recovered on the sieve and $15.0 \pm 2.4 \%$ was recovered on the filters.

\section{Microbial Utilization of DOC}

The concentration of DOC in the DOC flasks decreased rapidly due to growth of bacteria (Fig. 1). For both Syringodium filiforme and Thalassia testudinum the concentrations of DOC decreased to 20-30 $\mathrm{mg} \mathrm{DOC} \mathrm{l}^{-1}$ by Day 14. In the MPOC treatments, DOC concentrations increased from 6 to $10-15$ $\mathrm{mg} \mathrm{l}^{-1}$ and remained at that level for the duration of the experiment (Fig. 1).

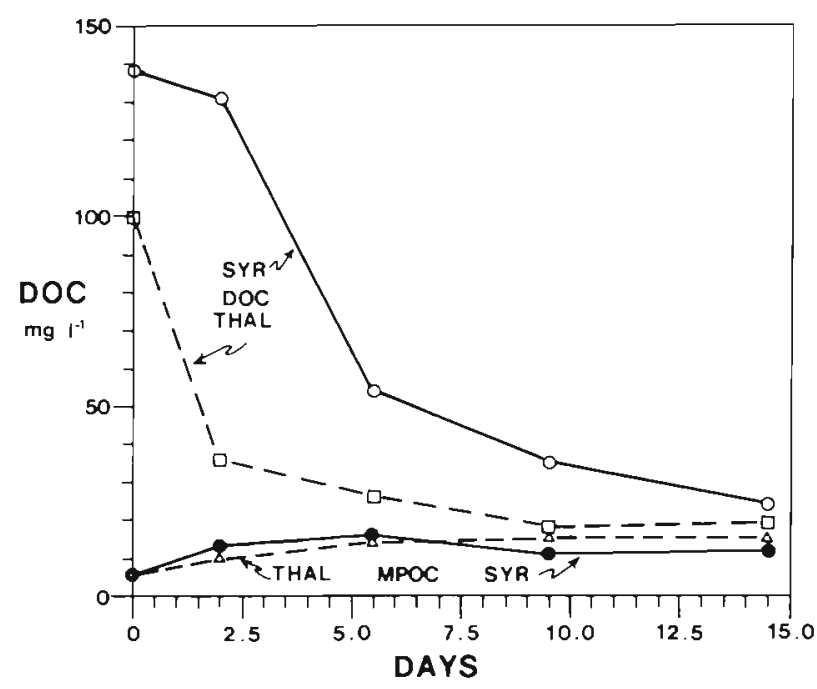

Fig. 1. Concentrations of dissolved organic carbon in the 4 experimental treatments during the microbial incubation period. Each point represents the mean of 3 replicates. The coefficient of error never exceeded $15 \%$ of the mean value for any point

\section{Growth of Microorganisms}

At all times during the incubation period, the numbers of microorganisms in the inoculated flask with no seagrass carbon added were at least 1.5-2 orders of magnitude less than in any of the treatments containing seagrass carbon. No aggregates were ever observed in the absence of added DOC. The coefficient of variation for cell counts of bacteria and protozoa averaged $40 \%$ and $54 \%$, respectively.

The mean bacterial cell volume for all treatments at all times was $0.24 \pm 0.01 \mu \mathrm{m}^{3}$ ( $\overline{\mathrm{x}} \pm 1$ S.E.M. $)$. The mean volumes of the flagellates and ciliates were 
$9.99 \pm 1.69 \mu \mathrm{m}^{3}$ and $255 \pm 29 \mu \mathrm{m}^{3}$, respectively. Because protozoan volumes varied from sample to sample, biomass calculations were made using the mean cell volume measurement for each sample. Biomass calculations for bacteria in all samples were made with the overall mean cell volume reported above, which did not vary greatly among samples or times.

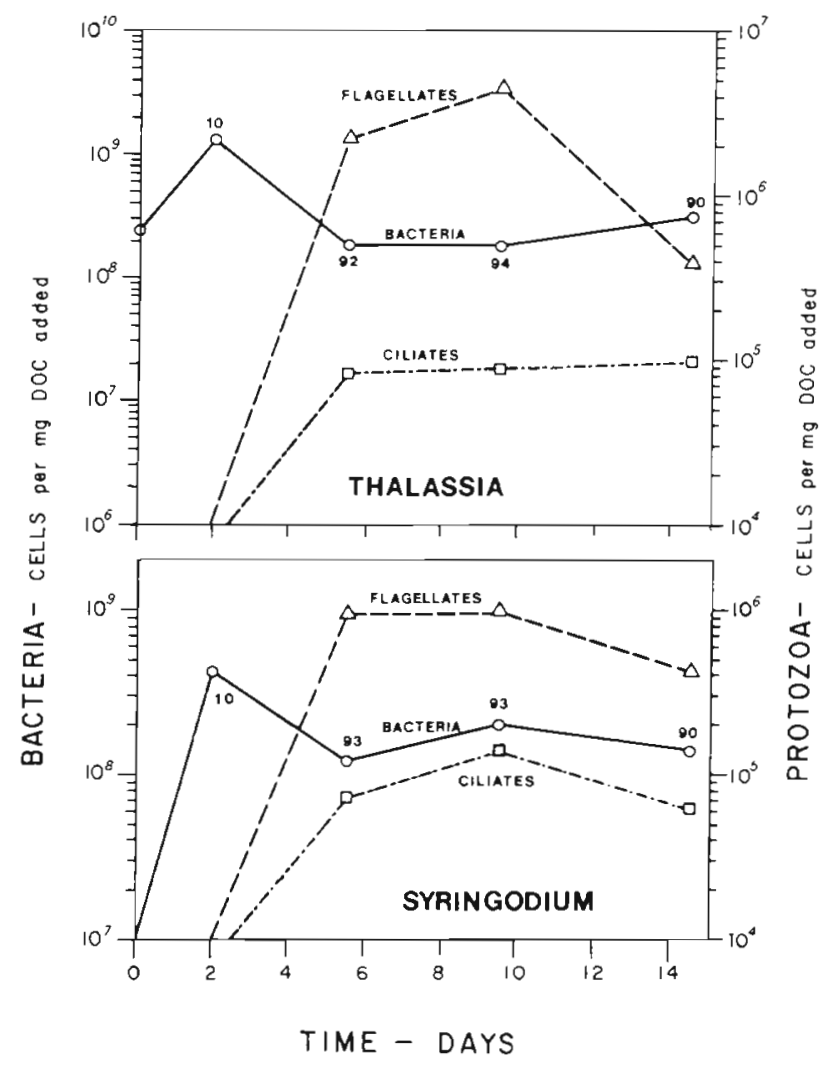

Fig. 2. Numbers of bacteria and protozoans in the flasks to which dissolved organic carbon was added. Each point represents the mean of 3 replicate flasks. Numbers near the points for the bacteria are the percentage of cells contained in aggregates

Bacterial populations increased rapidly in the DOC treatments of both seagrass species (Fig. 2). Maximum population levels were observed on Day 2 when bacteria numbered $1.3 \times 10^{9}$ cells $\mathrm{mg}^{-1}$ original Thalas-

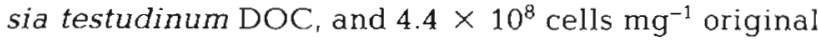
Syringodium filiforme DOC. This cell yield reflects a conversion efficiency of $0.88 \%$ and $2.72 \%$ for $S$. filiforme and $T$. testudinum, respectively.

On Day 2, very few aggregated bacterial cells were observed. However, from Day 5 until the end of the experiment, aggregated forms accounted for 90-95\% of the total bacterial numbers (Fig. 2). Under microscopic examination, the acridine orange stained aggregates consisted of densely packed bacterial cells embedded in an amorphous matrix which fluoresced a very pale, yellow-green color. The aggregates were irregularly shaped and ranged in size from a few cells up to clumps $5 \mathrm{~mm}$ in length; most were at least $50 \mu \mathrm{m}$ in length

The decline in total bacterial numbers after Day 2 was attributed to depletion of the readily available substrate and to grazing by protozoans. The ciliated and flagellated Protozoa observed were free-swimming forms that feed primarily on suspended, singlecelled bacteria. In both sets of treatments, the protozoans reached countable densities on Day 5, following the bacterial peak (Fig. 2). The rapid growth of Protozoa to numbers near $10^{6} \mathrm{mg}^{-1}$ original DOC demonstrated that the dissolved seagrass carbon was rapidly transferred through a microbial food chain starting with bacteria. The feeding activity of the Protozoa was thought to be one of the causes of the declining proportion of non-aggregated cells after Day 2, even though the number of total bacteria remained high. The calculated peak in protozoan carbon represented $0.07 \%$ of the original seagrass DOC for both species of seagrass. From Day 2 to Day 5, the production of protozoan carbon accounted for $11.7 \%$ (Syringodium filiforme) and $2.8 \%$ (Thalassia testudinum) of the decrease in bacterial carbon over the same period.

On Day 2, maximum bacterial numbers in the MPOC treatments averaged $5-6 \times 10^{7}$ cells $\mathrm{mg}^{-1}$ original MPOC $\left(1.0-1.2 \times 10^{-3} \mathrm{mg}\right.$ cell $\mathrm{Cmg}^{-1}$ MPOC) (Fig. 3). The total bacterial numbers remained relatively constant for the duration of the experiment. Aggregated bacteria were not observed in these flasks at any time.

During the study period, there was a pronounced shift towards a bacterial population dominated by leafattached cells (Fig. 3). On Day 0, no bacteria were observed on leached seagrass leaves. By Day 2, the leaf-attached bacteria constituted $40 \%$ of the total cells for both species of seagrass, and steadily increased, until by Day 5 the leaf-attached forms accounted for $75-85 \%$ of the total. The attached bacteria were more than $85 \%$ of the total counted for the remainder of the incubation.

The decline in suspended bacterial cell numbers between Days 2 and 5 coincided with the appearance of flagellates which had population maxima of 1-2 $\times 10^{5}$ cells $\mathrm{mg}^{-1}$ original MPOC (Fig. 3). These numbers correspond to biomasses of $2.4-4.5 \times$ $10^{-5} \mathrm{mg}$ protozoan $\mathrm{C} \mathrm{mg}^{-1}$ MPOC. Ciliates were occasionally observed in these samples but never reached quantifiable numbers. It appeared that the suspended bacterial and protozoan populations in these treatments were closely related, while the attached bacteria were independent of this trophic interaction. The maximum protozoan biomass attained (on Day 5) represented $4.9 \%$ and $8.2 \%$ of the decrease in suspended 


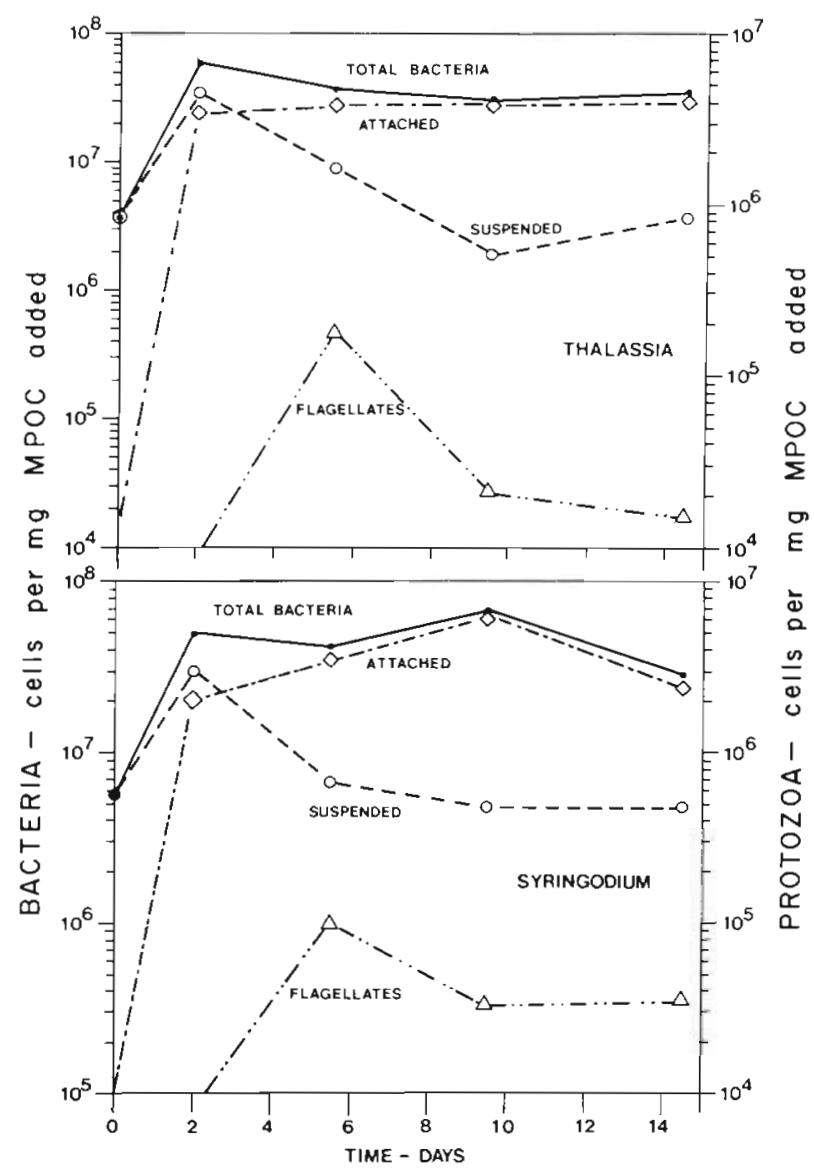

Fig. 3. Numbers of bacteria and protozoans in the flasks that contained macroparticulate organic matter. Each point represents the mean of 3 replicate treatment flasks

bacterial biomass from Day 2 to 5 in the Syringodium filiforme and Thalassia testudinum MPOC treatments, respectively.

\section{DISCUSSION}

The dried leaf material used in this study released $12.6 \%$ and $19.4 \%$ of its organic carbon as DOC for Thalassia testudinum and Syringodium filiforme, respectively. Because the material was dried, we cannot extrapolate to the DOC release from detrital leaves in nature. Concentrated pulses of DOC may be released by seagrasses under a variety of conditions. In the Florida Keys, seagrass beds are frequently exposed to high temperatures during low tides. The resulting desiccation and cellular damage causes a rapid loss of soluble organic compounds (Zieman, 1975). Similarly, large amounts of fresh leaf material are frequently detached from the plants and deposited in wrack lines on the shore. Such deposits are exposed to alternate wetting and drying, which leads to leaching and autolytic release of DOC.

Macro- and microscopic aggregates are common in coastal marine areas (Riley, 1963; Alldredge, 1976, 1979), and are frequently present in south Florida waters during periods following spring low tides, possibly as a result of pulse releases of seagrass DOC by the mechanisms outlined above. The results of the present experiments show that bacteria using seagrass DOC as a substrate readily form aggregates ranging in size from a few micrometers to a few millimeters. The association of bacteria with aggregates is common in areas of high primary productivity and high DOC concentrations (Paerl, 1974, 1975). De novo synthesis of aggregates from DOC has been attributed to bubble formation associated with bacterial action (Riley, 1963). Particle size increase has been attributed to physical-chemical flocculation (Kranck and Milligan, 1980) and agglomeration of microorganisms enhanced by high DOC concentrations (Paerl, 1974, 1975). Whatever the initial mechanism of particle formation from DOC, in this study the growth of aggregates was very clearly the result of biological processes. Only further study of aggregation can determine the necessary conditions under which the processes occur.

The DOC released by seagrass leaves in this study was utilized by the microorganisms more rapidly than the residual MPOC. Approximately 10 times more bacterial and protozoan carbon was produced per unit of added DOC than of MPOC during the incubation period, and the growth of suspended bacteria in the MPOC treatments was apparently insufficient to support a significant population of ciliates. These results corroborate the widely held assumption that the DOC released from macrophytes becomes available for consumers much more rapidly than the resistant components of the MPOC fraction. In nature, the feeding activities of detritivorous animals would increase the rate of microbial processing of the MPOC fraction (Hargrave, 1970; Morrison and White, 1980), but the inherently resistant nature of this fraction $(85 \%$ of the original carbon in this study) limits its rate of processing. Even so, its contribution to production would eventually exceed that of the DOC.

The bacterial biomass values reported in the present study are based on the total amount of seagrass carbon originally placed in the microcosms, and are thus lower than values calculated from the total amount of seagrass carbon carbon lost from the system. When calculated with the latter method, the bacterial carbon produced in the DOC treatments between Day 0 and Day 2 represents $4.0 \%$ of the Thalassia testudinum carbon and $16.9 \%$ of the Syringodium filiforme carbon lost during the same period (values are corrected for endogenous growth). Lucas et al. (1981), using mucil- 
age released from kelp as a substrate, reported average conversion efficiencies of $4.2 \%$ and $10.1 \%$ for winter and summer microbial populations, respectively (values recalculated to a carbon:carbon basis using the conversion values from the present work). The bacterial biomass values in the present study may be low due to 2 causes: (1) A systematic underestimate in calculating bacterial numbers in an aggregate; and (2) the extracellular matrix surrounding the aggregated bacteria was not included in the biomass estimates.

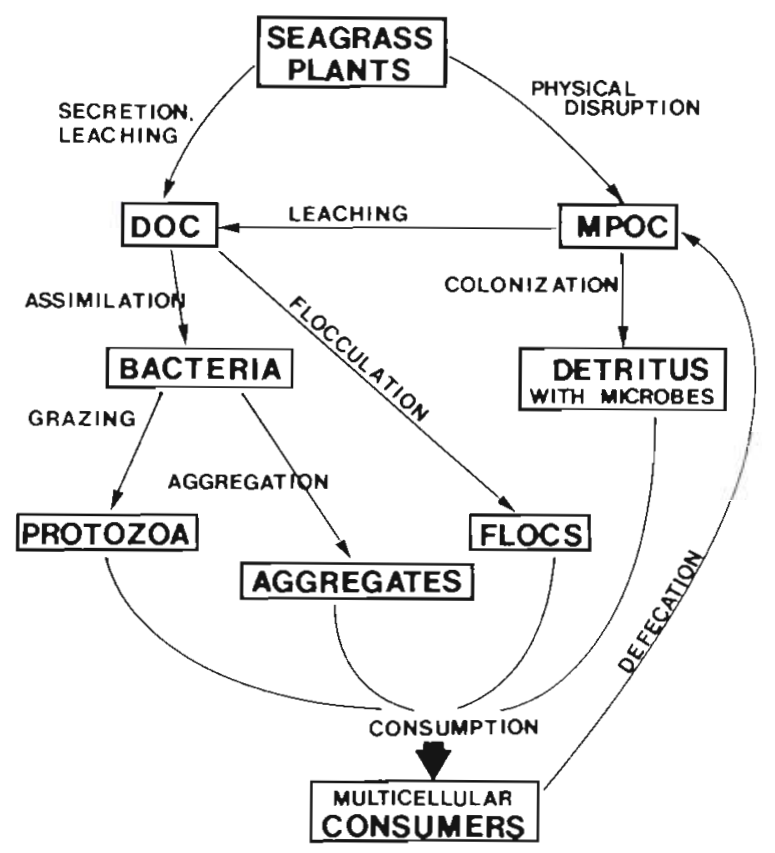

Fig. 4. Pathways of dissolved and particulate carbon flow through the initial stages of detritus-based food chains

Bacteria readily assimilate DOC and therefore are the primarly link between this fraction of macrophyte detrital carbon and consumers. Protozoa can feed on single-celled bacteria, and it has been shown that certain higher-order consumers such as Daphnia can filter bacteria, although at low efficiency (Peterson et al., 1978). Bacteria are nutritionally suitable food for other higher-order consumers such as copepods (Rieper, 1978), but utilization of bacteria as food is precluded for many animals because of their inability to trap individual cells (Fenchel, 1975). Therefore, the phenomena of protozoan grazing and bacterial aggregation observed in this study may increase the contribution of seagrass DOC to secondary productivity through the formation of food particles of more suitable size for a variety of marine consumers (Seki, 1972; Alldredge, 1976; Berk et al., 1977). Plant carbon can be converted to food particles for detrital consumers by all of the mechanisms depicted in Fig. 4. This conceptual model is presented primarily to distinguish between utilization of dissolved and particulate plant material. The contribution of particulate matter to higher order consumers involves colonization, decomposition, and disintegration by the microbes. Utilization of the dissolved fraction can occur through the uptake of DOC by bacteria, followed either by ingestion of the cells into intermediate consumers such as Protozoa, or by aggregation of the cells. Both events can result in synthesis of particles of a size that allows direct consumption by invertebrates or fish. Abiological flocculation of organic matter was not observed here, but may be of importance in some habitats.

The importance of each of the pathways to secondary productivity has received little study and certainly must vary from location to location, depending on considerations such as physical energy and DOC concentrations and release rates. Future research should be directed at quantitation of those pathways in light of these considerations.

Acknowledgements. The authors thank Gordon Thayer, Parke Rublee, W. Judson Kenworthy, Richard Newell and William E. Odum for critical reviews of the manuscript and many helpful suggestions. The use of the University of Virginia Reactor Facility and the assistance of the Facility staff are gratefully acknowledged. This study is a contribution of the Seagrass Ecosystem Study of the International Decade of Ocean Exploration, funded under grant OCE 77-27051.

\section{LITERATURE CITED}

Alldredge, A. L. (1976). Discarded appendicularian houses as sources of food, surface habitats, and particulate organic matter in planktonic environments. Limnol. Oceanogr. 21: $14-23$

Alldredge, A. L. (1979). The chemical composition of macroscopic aggregates in two neritic seas. Limnol. Oceanogr. 24: 855-866

Berk, S. G., Brownlee, D. C., Colwell, R. R., Heinle, D. R., Kling, H. J. (1977). Ciliates as a food source for marine planktonic copepods. Microb. Ecol. 4: 27-40

Brylinsky, M. (1977). Release of dissolved organic matter by some marine macrophytes. Mar. Biol. 39: 213-220

Dawes, C. J., Bird, K., Durako, M., Goddard, R., Hoffman, W., McIntosh, R. (1979). Chemical fluctuations due to seasonal and cropping effects on an algal-seagrass community. Aquat. Bot. 6: 79-89

Durbin, A. G., Durbin, E. G. (1975). Grazing rates of the Atlantic menhaden Brevoortia tyrannus as a function of particle size and concentration. Mar. Biol. 33: 265-277

Fenchel, T (1975). The quantitative importance of benthic microflora of an Arctic tundra pond. Hydrobiol. 46: 445-452

Fenchel, T. M., Jorgensen, B. B. (1977). Detritus food chains of aquatic ecosystems: the role of bacteria. In: Alexander, $M$. (ed.) Advances in microbial ecology, Vol. 1. Plenum Press, New York (6), pp. 1-58 
Ferguson, R. L., Rublee, P. (1976). Contribution of bacteria to standing crop of coastal plankton. Limnol. Oceanogr. 21. 141-145

Hargrave, B. T (1970). The effect of deposit-feeding amphipods on the metabolism of benthic microflora. Limnol. Oceanogr. 15: 21-30

Hobbie, J. E., Daley, R. J., Jasper, S. (1977). Use of Nuclepore filters for counting bacteria by fluorescence microscopy. Appl. environ. Microbiol. 33: 1225-1228

Kirkman, H., Reid, D. D. (1979). A study of the role of the seagrass Posidonia australis in the carbon budget of an estuary. Aquat. Bot. 7: 173-183

Kranck, K, Milligan, T. (1980). Macroflocs: production of marine snow in the laboratory. Mar. Ecol. Prog. Ser. 3: $19-24$

Lucas, M. I., Newell, R. C., Velmirov, B. (1981). Heterotrophic utilisation of mucilage released during fragmentation of kelp (EckJonia maxima and Laminaria pallida). II. Differential utilisation of dissolved organic components from kelp mucilage. Mar. Ecol. Prog. Ser. 4: 43-55

Mann, K. H. (1972). Macrophyte production and detritus food chains in coastal waters. Mem. 1st. Ital. Idrobiol. 29 (Suppl.): 353-383

Mills, A. L., Alexander, M. (1976). Factors affecting dimethylnitrosamine formation in samples of soil and water $\mathrm{J}$. Environ. Qual. 5: 437-440

Morrison, S. J., White, D. C. (1980). Effects of grazing by estuarine gammaridean amphipods on the microbiota of allochthonous detritus. Appl. Environ. Microbiol. 40: 659-671

Mullin, M. M. (1963). Some factors affecting the feeding marine copepods of the genus Calanus. Limnol. Oceanogr. 8: $239-250$

Odum, W. E., Heald, E. J. (1975). The detritus based food web of an estuarine mangrove community. In: Cronin, L. E. (ed.) Estuarine research, Vol. 1. Academic Press, New York, pp. 265-286

Otsuki, A., Wetzel, R. G. (1974). Release of dissolved organic matter by autolysis of a submerged macrophyte, Scirpus subterminalis. Limnol. Oceanogr. 19: 842-845

Owen, G. (1974). Feeding and digestion in the bivalvia. In: Lowenstein, O. (ed.) Adv. Comp. Phys. Biochem. 5: 1-35
Paerl, H. W. (1974). Bacterial uptake of dissolved organic matter in relation to detrital aggregation in marine and freshwater systems. Limnol. Oceanogr. 19: 966-972

Paerl, H. W. (1975). Microbial attachment to particles in marine and freshwater systems. Microb. Ecol. 2: 73-83

Penhale, P. A., Smith, W. O., Jr. (1977). Excretion of dissolved organic carbon by eelgrass (Zostera marina) and its epiphytes. Limnol. Oceanogr. 22: 400-407

Peterson, B. J., Hobbie, J. E., Haney, J. F. (1978). Daphnia grazing on natural bacteria. Limnol. Oceanogr 23: $1039-1044$

Rieper, M. (1978). Bacteria as food for marine harpacticoid copepods. Mar. Biol. 45: 337-345

Rigler, F. H., MacCallum, M. E., Roff, J. C. (1974). Production of zooplankton in Char Lake. J. Fish. Res. Bd Can. 31: 631-646

Riley, G. A. (1963). Organic aggregates in seawater and the dynamics of their formation and utilization. Limnol. Oceanogr. 8: 372-381

Rublee, P., Cammen, L., Hobbie, J. E. (1978). Bacteria in a North Carolina salt marsh: standing crop and importance in the decomposition of Spartina alterniflora. UNC Sea Grant Pub. \# UNC-SG-78-11. Aug. 1978. Univ. North Carolina

Seki, H. (1972). The role of microorganisms in the marine food chain with reference to organic aggregates. Mem. 1st. Ital. Idrobiol. 29 (Suppl.): 245-254

Tenore, K. R. (1975). Detrital utilization by the polychaete, Capitella capitata. J. mar Res. 33: 261-274

Tenore, K. R. (1977). Growth of the polychaete, Capitella capitata cultured on different levels of detritus derived from various sources. Limnol. Oceanogr 22: 936-941

Westlake, D. F. (1963). Comparisons of plant productivity. Biol. Rev. 38: 385-425

Wetzel, R. G., Penhale, P. A. (1979). Transport of carbon and excretion of dissolved organic carbon by leaves and roots/ rhizomes in seagrasses and their epiphytes. Aquat. Bot. 6: $149-158$

Zieman, J. C. (1975). Quantitative and dynamic aspects of the ecology of turtle grass Thalassia testudinum. In: Cronin, L. E. (ed.) Estuarine research, Vol. 1. Academic Press, New York, pp. 541-562

This paper was presented by Professor T. Fenchel; it was accepted for printing on November 2, 1981 